\title{
A comparative assessment of prediction capabilities of Dempster-Shafer and Weights- of-evidence models in landslide susceptibility mapping using GIS
}

\author{
HamidReza Pourghasemi , Biswajeet Pradhan , Candan Gokceoglu \& Kimia \\ Deylami Moezzi
}

To cite this article: HamidReza Pourghasemi , Biswajeet Pradhan, Candan Gokceoglu \& Kimia Deylami Moezzi (2013) A comparative assessment of prediction capabilities of Dempster-Shafer and Weights-of-evidence models in landslide susceptibility mapping using GIS, Geomatics, Natural Hazards and Risk, 4:2, 93-118, DOI: 10.1080/19475705.2012.662915

To link to this article: https://doi.org/10.1080/19475705.2012.662915

\section{(2) Copyright Taylor and Francis Group, LLC}

\section{Published online: 23 Apr 2012.}

6 Submit your article to this journal

Џlll Article views: 1350

Q View related articles $\sqsubset$

Citing articles: 110 View citing articles $\square$ 


\title{
A comparative assessment of prediction capabilities of Dempster-Shafer and Weights-of-evidence models in landslide susceptibility mapping using GIS
}

\author{
HAMIDREZA POURGHASEMI $\dagger$, BISWAJEET PRADHAN*†, \\ CANDAN GOKCEOGLU§ and KIMIA DEYLAMI MOEZZI \\ $\dagger$ Department of Watershed Management Engineering, College of Natural Resources and \\ Marine Sciences, Tarbiat Modares University International Campus, Iran \\ IInstitute of Advanced Technology (ITMA), Spatial \& Numerical Modeling Laboratory, \\ University Putra Malaysia, 43400, Serdang, Selangor, Malaysia \\ $\S$ Applied Geology Division, Department of Geological Engineering, \\ Engineering Faculty, Hacettepe University, Ankara, Turkey \\ \B. Sc. graduate of environment, Iran
}

(Received 8 October 2011; in final form 30 January 2012)

In a country with diverse geologic, topographic and climatic conditions such as Iran, landslides are frequent phenomena. The aim of this study is to perform a landslide susceptibility assessment at Haraz watershed, Iran using two different approaches such as Dempster-Shafer and Weights-of-evidence models in GIS. First, a landslide inventory map was prepared using the landslide occurrence data by interpreting aerial photographs and field surveys. Second, thematic maps including lithology, altitude, and land-use are prepared in GIS. A total 11 landslide conditioning factors are considered such as slope angle, aspect, altitude, distance from drainage, distance from road, distance from river, lithology, land use, topographic wetness index, stream power index and slope-length (LS). The relationship between the conditional factors and the landslides were calculated using both Dempster-Shafer and Weights-of-evidence models. Using the predicted values, landslide susceptibility maps of the study area is produced. For verification, the results of the analyses were then compared with the fieldverified landslide locations. Additionally, the receiver operating characteristics (ROC) curves for all landslide susceptibility models were drawn and the area under curve values was calculated. The AUC value of the produced landslide susceptibility maps has been obtained as $72.87 \%$ and $79.87 \%$ for DempsterShafer and Weights-of-evidence models, respectively. The resulting susceptibility maps would be useful for landuse planning and prioritization of efforts for the reduction and mitigation of future landslide hazards in Haraz watershed.

\section{Introduction}

Landslide is defined as the movement of a mass of rock, debris or earth down a slope (Cruden 1991). Other terms used to refer to landslide events include mass

\footnotetext{
*Corresponding author. Email: biswajeet24@gmail.com; biswajeet@mailcity.com
} 
movement, slope failures, slope instability and terrain instability (Gerath et al. 1997). Due to natural conditions or man-made actions, landslides have produced multiple human and economic losses. Landslides result from interdependent, spatio-temporal processes, including hydrology (rainfall, evaporation, transpiration and groundwater, vegetation surcharge (weight of vegetation), root strength, soil and bed rock condition, topography and human activities (Gerath et al. 1997). Human activities, such as urban expansion and deforestation, also increase the potential for landslides and result in adverse impacts to the environment. The recent increasing of land-use changes has raised the level of landslide susceptibility, particularly in mountainous regions. Guzzetti et al. (1999) asserted that, over the last two decades, many governments and international research institutes in the worldwide have invested considerable resources in assessing landslide hazards and in attempting to construct maps that describe their spatial distribution (Guzzetti et al. 1999).

Landslides have caused large numbers of casualties and huge economic losses in hilly and mountainous areas of the world (Varnes 1984). Landslide is one of the main natural hazards in Iran that annually makes great economic and personal defect. Primary estimations show that annual fiscal defects of landslide are about 500 billion Rials (about USD 600 Million) which does not involve the loss of unrecoverable resources (ILWP 2007). Mountainous feature, high tectonic activity, geological and climatologically variety make the Iranian plateau capable for the occurrence of various kinds of landslides. In the northern part of Iran (Alborz mountain belt), landslides occur frequently due to climatologic and geologic conditions and high tectonic activities, that results, annually, millions of dollars financial defect excluding casualties and unrecoverable resources. As an example, in Iran's northern province of Mazandaran (January 2007), a landslide has inflicted heavy damages on the water, power communication installations, utilities and a large number of residential units in the stricken area. This incident started initially with a slow landslip in the area, which has accelerated and turned into a landslide, damaging 20 villages. The costs of damages have been estimated about USD 5,000,000. It is difficult to ignore the huge losses to buildings, roads, rails, power lines, water lines, mineral equipment, oil industry, urban infrastructures, dams, forests, natural resources, farming lands and rural areas caused by landslide. In addition to physical losses, landslides caused environmental damage.

During the recent decades, the use of landslide susceptibility and hazard maps for land use planning has increased significantly. These maps rank different sections of land surface according to the degree of actual or potential landslide hazard; thus planners are able to choose favourable sites for urban and rural development. In recent years, the use of GIS for landslide hazard modelling has been increasingly used. It is because of the development of commercial systems and the quick access to data obtained through Global Positioning Systems (GPS) and remote sensing. Moreover, GIS is an excellent and useful tool for the spatial analysis of a multidimensional phenomenon such as landslides and for the landslide susceptibility mapping (Van Westen et al. 2003). Over the last decades, a number of different methods for landslide susceptibility mapping have been used and suggested. The process of creating these maps includes several qualitative or quantitative approaches (Soeters and Van Westen 1996). Early attempts defined susceptibility classes by the qualitative overlaying of geological and morphological slope-attributes to landslide inventories (Nilsen et al. 1979). 
Many studies have been carried out on landslide hazard evaluation using GIS; for example, Guzzetti et al. (1999) summarized many landslide hazard evaluation studies. Recently, there have been studies on landslide susceptibility evaluation using GIS, and many of these studies have applied probabilistic models (Gokceoglu et al. 2005). Logistic regression model, one of the most widely used statistical models, has also been employed for the purpose of landslide susceptibility mapping (Can et al. 2005, Gorsevski et al. 2006, Nefeslioglu et al. 2008, Pradhan 2010a, 2010b, 2010c, Pradhan et al. 2010a, Pradhan and Youssef 2010, Chauhan et al. 2010, Bui et al. 2011a). Data mining using fuzzy logic (e.g. Ercanoglu and Gokceoglu 2002, 2004, Champati ray et al. 2007, Kanungo et al. 2008, Pradhan 2010c, 2011a, 2011b), artificial neural networks (Ermini et al. 2005, Lee et al. 2006, Pradhan and Buchroithner 2010, Pradhan and Lee 2010a, b, c, Pradhan and Pirasteh 2010), decision tree (Saito et al. 2009, Wan 2009, Akgun and Turk 2010, Gorsevski and Jankowski 2010, Nefeslioglu et al. 2010, Yeon et al. 2010) and neuro-fuzzy (Lee et al. 2009, Pradhan et al. 2010c, Vahidnia et al. 2010, Oh and Pradhan 2011, Bui et al. 2011b, Sezer et al. 2011) models have also been applied using geographical information system (GIS). In recent years, Dempster-Shafer and Weights-of evidence models has also been used for the purpose of landslide susceptibility mapping (Tangestani 2009, Park 2011, Lee and Choi 2004, Mathew et al. 2007, Neuhauser and Terhorst 2007, Pradhan et al. 2010b).

This article evaluated the susceptible areas in Haraz wateshed located in north part of Iran using Dempster-Shafer and Weights-of evidence models, GIS and remote sensing techniques. The main difference between the present study and the approaches described in the aforementioned publications is that a Dempster-Shafer and Weights-of-evidence models were applied and their results were compared for landslide susceptibility mapping at Haraz watershed, Iran. Final susceptibility map might be useful for decision making process about land use management in the future in order to avoid more losses.

\section{Study area}

The study area is located in the north of Iran, which is one of the most landslideprone areas in the country (Pourghasemi 2008). The watershed area lies between longitudes $52^{\circ} 06^{\prime} 02^{\prime \prime} \mathrm{E}$ and $52^{\circ} 18^{\prime} 13^{\prime \prime} \mathrm{E}$ and latitudes between $35^{\circ} 49^{\prime} 05^{\prime \prime} \mathrm{N}$ and $35^{\circ} 57^{\prime} 39^{\prime \prime} \mathrm{N}$. The study area is mountainous with rugged topography and part of Alborz folded zone (figure 1). It covers two adjacent 1:50,000 topographic sheets of the Army Geographic Institute of Iran and has an extent of about $114.5 \mathrm{~km}^{2}$. The main river in the study area is the Haraz river. Based on Iranian Meteorological Department, The temperature varies between $25^{\circ} \mathrm{C}$ in winter and $36.5^{\circ} \mathrm{C}$ in summer. The mean annual rainfall is around $500 \mathrm{~mm}$, most of which falls between November and January. The altitudes in the study area vary between 1200 and $3290 \mathrm{~m}$. The slope angles of the area range from 0 degrees to as much as 70 degrees. The majority of the area $(64.82 \%)$ is covered by moderate pasture. The other parts of the study area are utilized for orchard and agricultural $(13.33 \%)$, residential $(0.3 \%)$ and pasture purposes $(21.55 \%)$. The study area is covered by various types of lithologic formations, such as Quaternary, Eocene, Paleocene, late Cetaceous, late Jurassic, early Triassic and early Permian. The Quaternary deposits cover about $40 \%$ of the study area. 

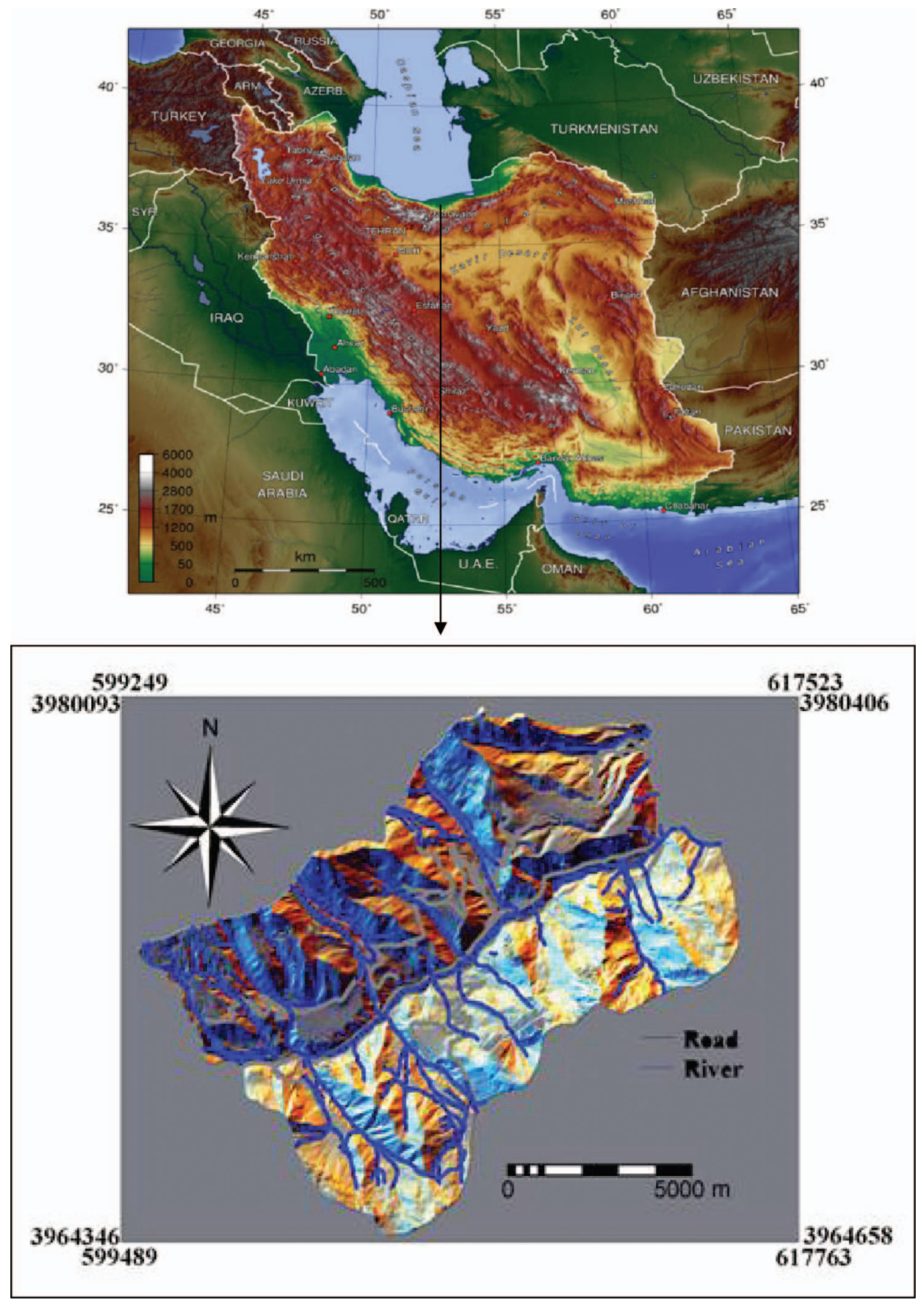

Figure 1. Location map of the study area.

\section{Data and methodology}

The first step in every assessment consists of collecting all available information and dataset on the study area (Guzzetti et al. 1999). For the landslide-susceptibility 
analysis, the main steps were data collection and construction of a spatial database from which the relevant factors were extracted, followed by assessment of the landslide susceptibility using the relationship between the landslide and landsliderelated factors, and validation of the results (Pradhan and Lee 2010c). A spatial database of the Haraz watershed related to landslide susceptibility modelling was compiled. The spatial database is mainly composed of two parts such as landslide location map and landslide conditioning factors.

\subsection{Landslide inventory map}

Preparation of landslide inventory is one of the most important stages in landslide hazard mitigation. These maps show the locations and properties of landslides that have occurred in the past. These slope failures were related to geological, topographical and climatic conditions. It is important to determine the location and area of the landslide accurately when preparing the landslide susceptibility maps. Landslide susceptibility assessment is performed in a range of phases. The initial phase is identifying and evaluating landslide-prone areas, and constructing a landslide inventory map for future use. Landslide inventory mapping is the systematic mapping of existing landslides in a region using different techniques such as field survey, air photo/satellite image interpretation, and literature search for historical landslide records (Yalcin et al. 2011). A landslide inventory map provides the spatial distribution of locations of existing landslides. The landslides in the study area were determined by comprehensive field surveys. In this study, the susceptibility mapping started with the preparation of an inventory map of 78 landslides from field studies (figure 2). Of the 78 landslides identified, randomly 55 $(70 \%)$ locations were chosen for the landslide susceptibility maps, while the remaining $23(30 \%)$ cases were used for the model validation. The size of the smallest and largest landslide is $50 \mathrm{~m}^{2}$ and $5400 \mathrm{~m}^{2}$, respectively. Figure 3 shows some field photographs taken during April 2007. These landslides were then classified based on their modes of occurrence using the classification scheme proposed by Varnes (1978). Most of the landslides are shallow rotational with a few translational. However, during the analyses performed in the present study, only rotational failure is considered and translational slides were eliminated because its occurrence is rare.

\subsection{Landslide conditioning factors}

In this study, 11 factors were considered which are slope angle, altitude, slope aspect, distance from river, distance from road, topographic wetness index, stream power index, slope-length (LS) factor, lithology, distance from fault, and land use. These factors can be divided into three broad categories which are topographical, geological and environmental conditioning parameters. The availability of thematic data varies widely, depending on the type, scale, and method of data acquisition. These eleven factors were extracted from the constructed GIS-based spatial database.

For DEM creation, $20 \mathrm{~m}$ interval contours and surveyed base points showing the elevation values were extracted from the 1:50,000 scale topographic maps. Using the DEM, slope angle, altitude, slope aspect, topographic wetness index, stream power index and stream transport index were calculated. For the landslide susceptibility 


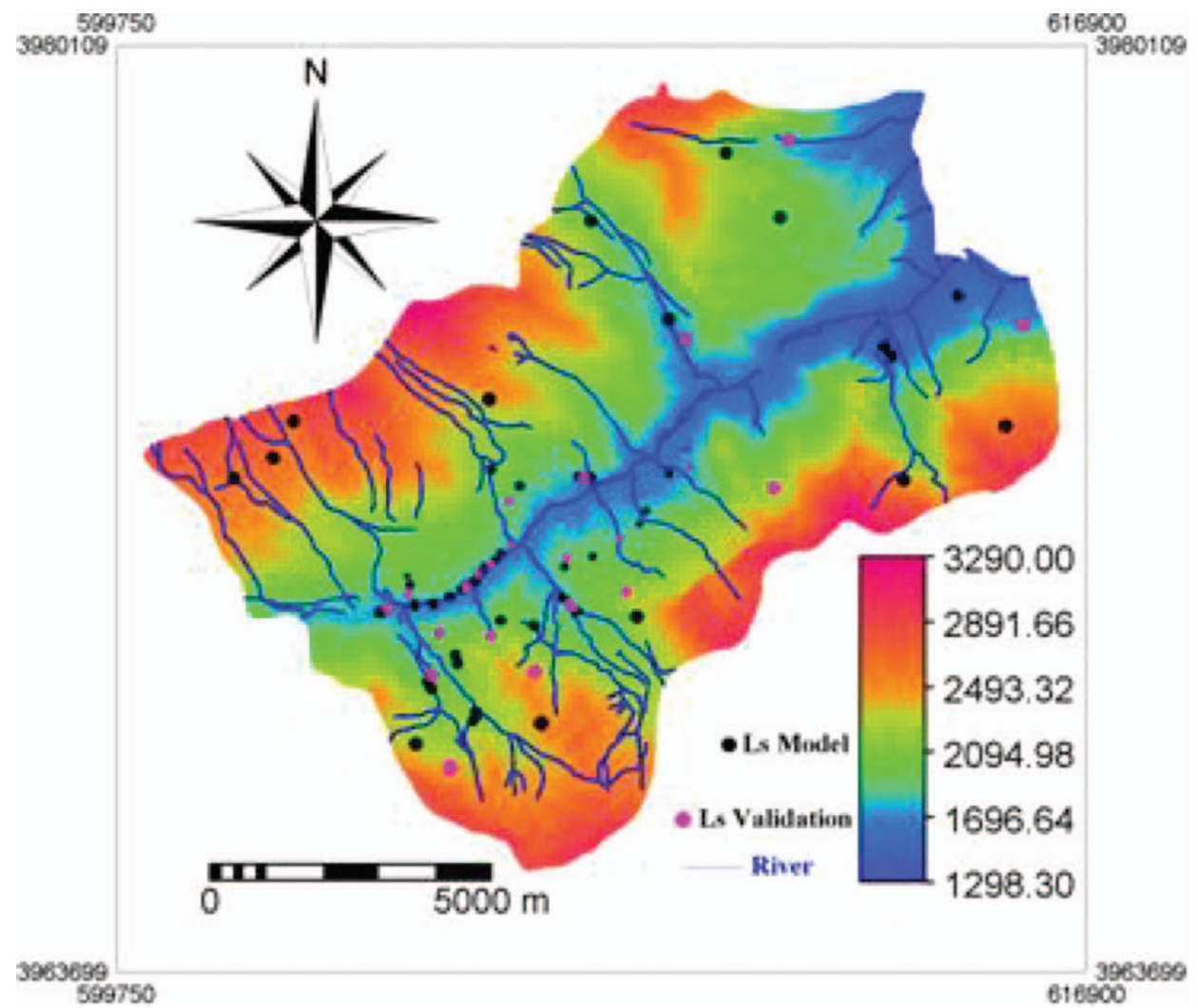

Figure 2. Landslide inventory map of the study area.

assessment the slope angle was classified into six classes $\left(0-5^{\circ}, 5-15^{\circ}, 15-30^{\circ}, 30-50^{\circ}\right.$, $50-70^{\circ}$ and $>70^{\circ}$ ) (figure 4 ). The slope aspects are grouped into nine classes: flat, north $\left(337.5^{\circ}-360^{\circ}, 0^{\circ}-22.5^{\circ}\right)$, north-east $\left(22.5^{\circ}-67.5^{\circ}\right)$, east $\left(67.5^{\circ}-112.5^{\circ}\right)$, southeast $\left(112.5^{\circ}-157.5^{\circ}\right)$, south $\left(157.5^{\circ}-202.5^{\circ}\right)$, south-west $\left(202.5^{\circ}-247.5^{\circ}\right)$, west $\left(247.5^{\circ}-\right.$ $\left.292.5^{\circ}\right)$ and north-west $\left(292.5^{\circ}-337.5^{\circ}\right)$. The topography has a vital role in the spatial variation of hydrological conditions such as soil moisture, groundwater flow and slope stability. Topographic indices have, therefore, been used to describe spatial soil moisture patterns (Moore et al. 1991). The Stream power index (SPI) is a compound topographic attribute. It is a measure of the erosive power of flowing water based on the assumption that discharge is proportional to specific catchment area. It generally predicts net erosion in areas of profile and tangential convexity (flow acceleration and convergence zones) and net deposition in areas of profile concavity (zones of decreasing flow velocity). Stream power index was calculated based on the formula given by Moore et al. (1991).

$$
S P I=A_{S} \times \tan \beta
$$

where $A_{S}$ is the specific catchment's area and $\beta$ is the local slope gradient measured in degrees. Another topographic factor within the runoff model is the topographic wetness index (TWI). A topographic wetness index measures the degree of 


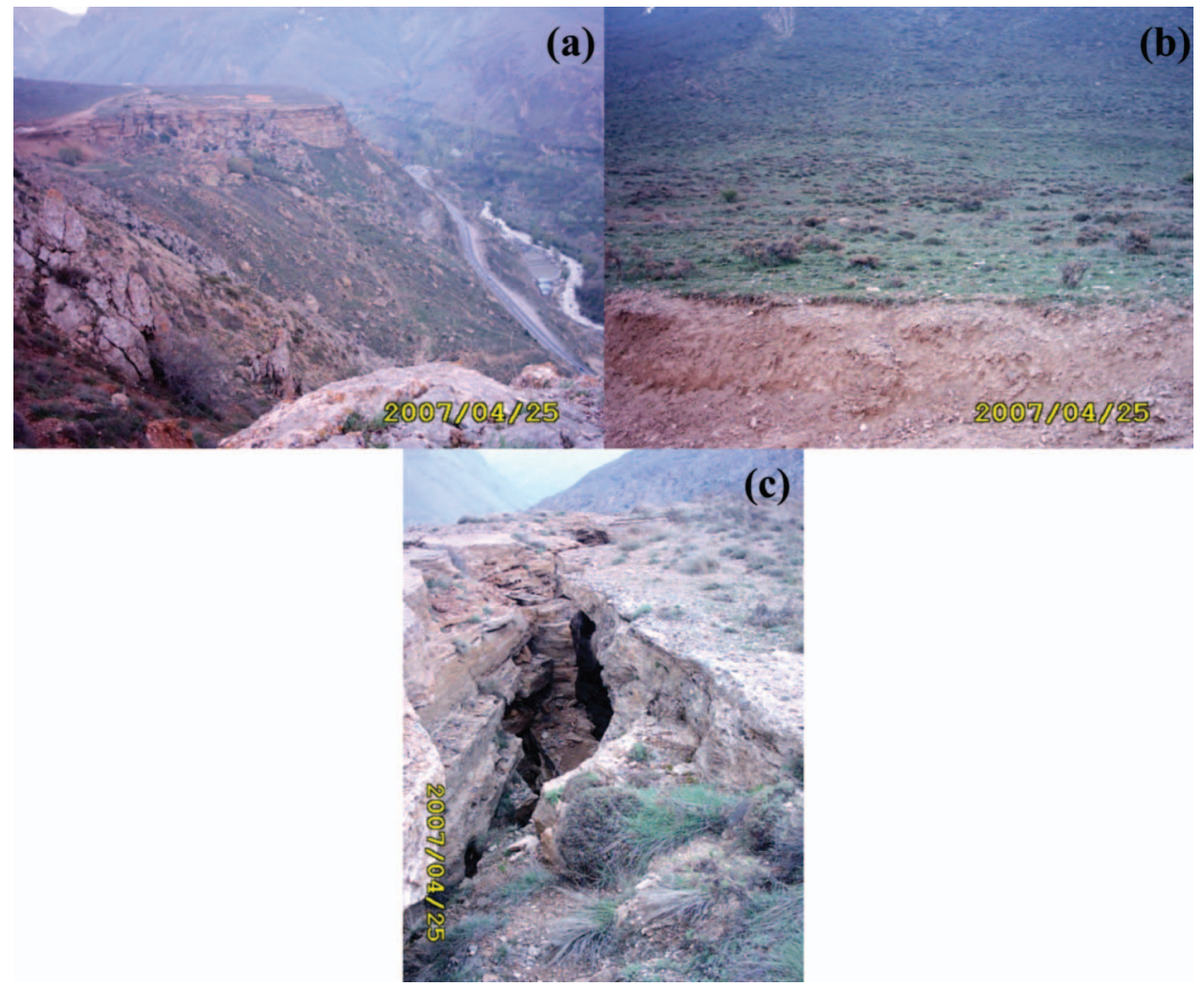

Figure 3. Shows some field photographs (a) shows a landslide in study area between Tehran and Mazandaran Province (b) and (c) small scale landslides.

accumulation of water at a site. It is defined as (Beven and Kirkby 1979, Moore et al. 1991):

$$
T W I=\ln (a / \tan \beta)
$$

Where $a$ is the cumulative upslope area draining through a point (per unit contour length) and $\tan \beta$ is the slope angle at the point. The $\ln (a / \tan \beta)$ index reflects the tendency of water to accumulate at any point in the catchment (in terms of a) and the tendency of gravitational forces to move that water down slope (expressed in terms of $\tan b$ as an approximate hydraulic gradient). The water infiltration primarily depends upon material properties such as permeability, pore water pressure, and effects on the soil strength (Poudyal et al. 2010). In this study, TWI was considered as another contributing factor. Besides, the stream power index and topographic wetness index, there is another factor is also included i.e. slope-length (LS). The soil loss is a combined effect of length $(L)$ and slope steepness $(S)$. The LS factor in the Universal Soil Loss Equation (USLE) is a measure of the sediment transport capacity of overland flow (Moore and Wilson 1992). Slope-length is the distance from the origin of overland flow along its flow path to the location of either concentrated flow or deposition. The larger slope length, the more water accumulates at the bottom of the field, increasing erosion. It also depends on the surface slope. Carrara et al. (1995) stated that there is a relation between slide density 


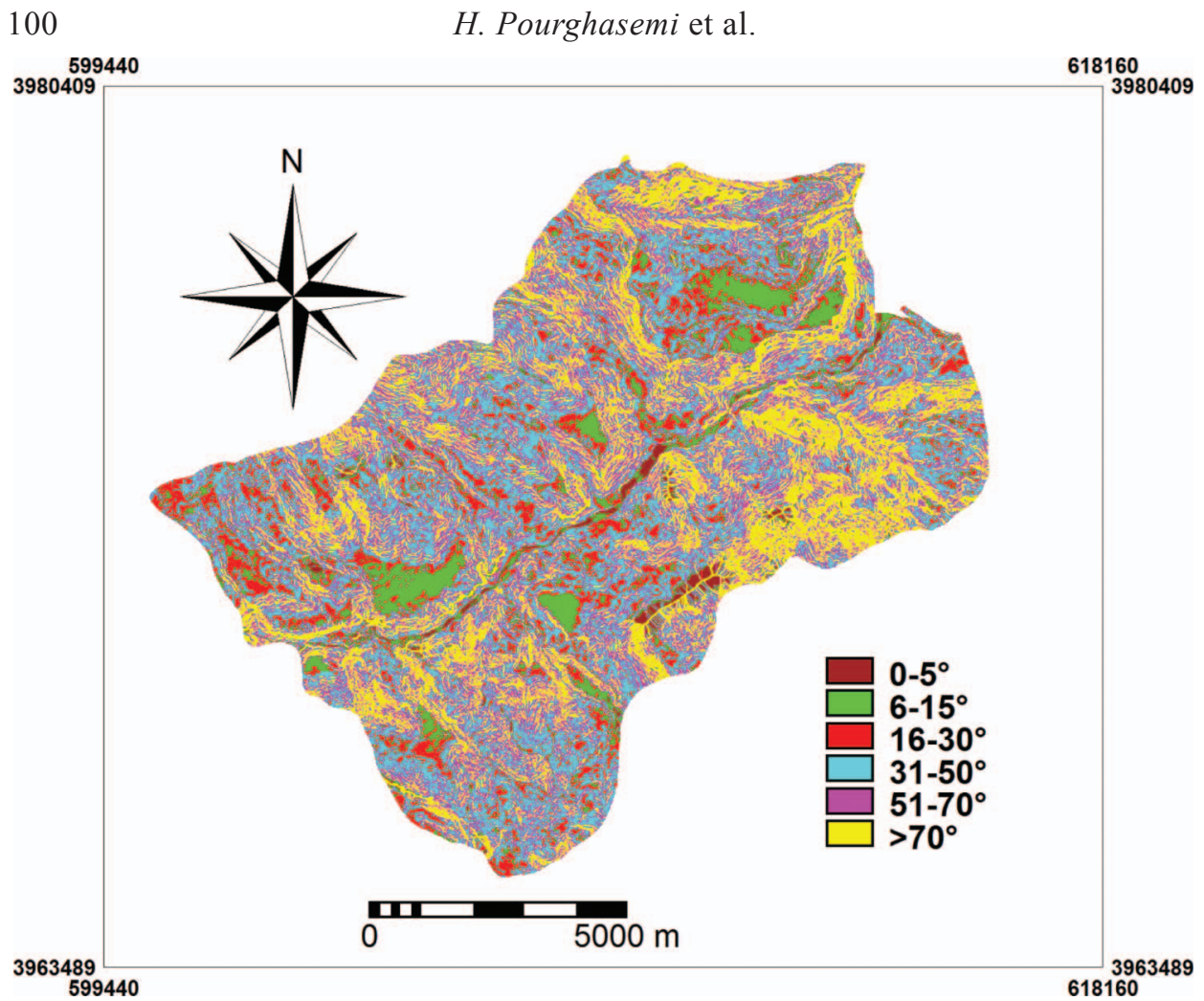

Figure 4. The slope map of the study area.

and slope length. The slope length factor was calculated based on work by Moore and Burch (1986) as

$$
L S=\left(\frac{A_{S}}{22.13}\right)^{0.6}\left(\frac{\sin \beta}{0.0896}\right)^{1.3}
$$

These indices can be estimated as a function of primary terrain attributes and can be easily implemented in a SAGA GIS.

In addition, the distance from river and distance from road were calculated using the topographic database. The river and road buffer were calculated in 100 meter intervals. The lithology map was prepared from a 1:100,000 scale geological map (source: geology survey of Iran, (GSI)). The study area is covered by various types of lithologic formations. The general geological setting of the area is shown in figure 5 and table 1 . The distance from fault was calculated in 100 meter intervals. Land use data were classified from $E_{T} M^{+}$satellite images using a supervised classification method and field surveys. Four types of landuse are identified such as good range, moderate range, mixed orchard and agricultural and residential area (figure 6). The collected data were converted to a raster grid with $25 \mathrm{~m} \times 25 \mathrm{~m}$ cells for application of the two different methods namely, Dempster-Shafer, and Weights-of evidence models. 


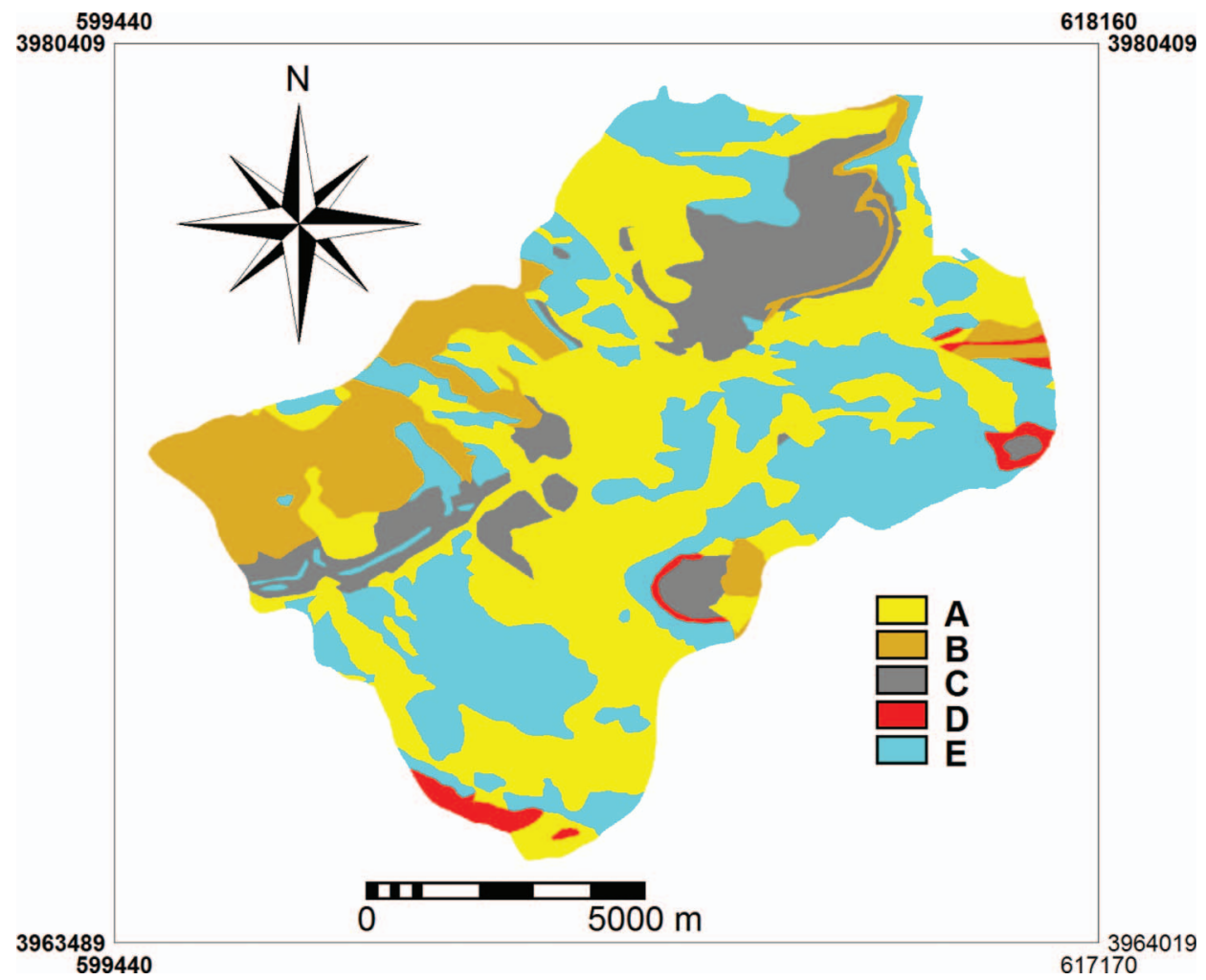

Figure 5. The lithology map of the study area.

\section{Results and discussion}

\subsection{Landslide susceptibility mapping by Dempster-Shafer theory}

In landslide susceptibility analysis based on the Dempster-Shafer theory (DSET), a structure of discernment can be considered as follow (Dempster 1967; Shafer 1976):

$$
m: 2^{\Theta}=\left\{\phi, T_{P}, \overline{T_{P}}, \Theta\right\} \quad \text { With } \Theta=\left\{T_{P}, \overline{T_{P}}\right\}
$$

Where $T_{P}$ indicates a goal: "At each pixel p, it will be influenced by future landslides". The opposite goal proposition can be written as "At each pixel $p$, it will not be influenced by future landslides" is showed as $\overline{T_{P}}$. In literature, it is possible to find the studies (i.e. Park 2011) giving the details of the Dempster-Shafer theory. As mentioned earlier, by using DSET to landslide susceptibility analysis is to define mass functions employing quantitative relationships in between the known landslides and input conditioning factors. In this article, the mass functions are calculated by a likelihood ratio function, which separate the susceptible areas from the non-susceptible areas. In this context, the suitability of spatial data in landslide susceptibility analysis is distinguishing between the susceptible and non-susceptible areas. In the frequency distribution functions, the function ratios can emphasis on differences. For landslide susceptibility analysis layer of spatial data is considered as evidence $B_{i}(i=1,2, \ldots, l)$ for the target proposition $T_{P}$. Given the $B_{i j}$, which is the $j$ th 
Table 1. Geologic formation of the study area.

\begin{tabular}{|c|c|c|c|c|}
\hline Code & Class & Formation & Lithology & Geological age \\
\hline$Q^{s c}$ & A & - & Scree & Quaternary \\
\hline$Q_{2}^{t}$ & & - & Young terraces & Quaternary \\
\hline$Q_{1}^{t}$ & & - & Old terraces & Quaternary \\
\hline$Q^{a g}$ & $\mathrm{~B}$ & - & Agglomerate & Quaternary \\
\hline$Q^{t a}$ & & - & Trachy andesitic lava flows & Quaternary \\
\hline$Q^{t u}$ & & - & Ash tuff, lapilli tuff & Quaternary \\
\hline$Q^{b}$ & & - & Olivine basalt & Quaternary \\
\hline$K_{k}^{t v}$ & $\mathrm{C}$ & Karaj & $\begin{array}{l}\text { Green tuff, basaltic and limestone } \\
\text { with gypsum and conglomerate }\end{array}$ & Eocene \\
\hline$E_{k}^{g y}$ & & Karaj & Gypsum & Eocene \\
\hline$P E_{z}$ & $\mathrm{D}$ & Ziarat & $\begin{array}{l}\text { Limestone bearing nummulites and } \\
\text { alveolina, conglomerate }\end{array}$ & Paleocene \\
\hline$P E_{f}$ & & Fajan & $\begin{array}{l}\text { Conglomerate, agglomerate, some } \\
\text { marl and limestone }\end{array}$ & Paleocene \\
\hline$K_{2}$ & $\mathrm{E}$ & - & Biogenic and cherty limestone & Late Cretaceous \\
\hline$K_{t}$ & & Tizkuh & Orbitoline bearing limestone & Late Cretaceous \\
\hline$J_{1}$ & & Lar & $\begin{array}{l}\text { Massive to well bedded, cherty } \\
\text { limestone }\end{array}$ & Late Jurassic \\
\hline$J_{d}$ & & Dalichai & $\begin{array}{l}\text { Well bedded, partly oolitic-detritic } \\
\text { limestone, marly limestone }\end{array}$ & Late Jurassic \\
\hline$J_{S}$ & & Shemshak & $\begin{array}{l}\text { Dark shale and sandstone with plant } \\
\text { remains, coal }\end{array}$ & Late Jurassic \\
\hline$T R_{e L}$ & & Elika & Thin bedded limestone & Early Triassic \\
\hline $\mathrm{P}_{\mathrm{d}}$ & & Dorud & Cross bedded, quartzitic sandstone & Early Permian \\
\hline
\end{tabular}

class feature of the evidence $B_{i}$ and frequency distribution functions of positive and opposite target propositions, the likelihood ratio $\lambda\left(T_{P}\right)_{B j i}$ for affirming the positive target proposition is defined as follow:

$$
\left(T_{P}\right)_{B j i}=\frac{\frac{N\left(A \cap B_{i j}\right)}{N(A)}}{\frac{N\left(B_{i j}\right)-N\left(A \cap B_{i j}\right)}{N(C)-N(A)}}
$$

Where $N\left(A \cap B_{i j}\right)$ is the density of landslide pixels that occurred in $B_{i j}, N(A)$ is the total density of whole landslides that have occurred in the study area, $N\left(A_{i j}\right)$ is the density of pixels in $B_{i j}$, and $N(C)$ is the density of pixels in the whole study area $C$. The numerator and denominator are the proportion of the susceptible and nonsusceptible areas in the given attribute $B_{i j}$, respectively. In the weights-of-evidence model (Bonham-Carter 1994), a positive weight is usually defined as the natural logarithm of the likelihood ratio in equation 5. Consequently, the likelihood ratio for affirming the opposite target proposition is defined as follow:

$$
\left(\overline{T_{P}}\right)_{B j i}=\frac{\frac{N(A)-N\left(A \cap B_{i j}\right)}{N(A)}}{\frac{N(C)-N(A)-N\left(B_{i j}\right)+N\left(A \cap B_{i j}\right)}{N(C)-N A)}}
$$

Where the numerator and denominator are the proportion of non-susceptible and susceptible areas in the given attribute $B_{i j}$. A negative weight in the 


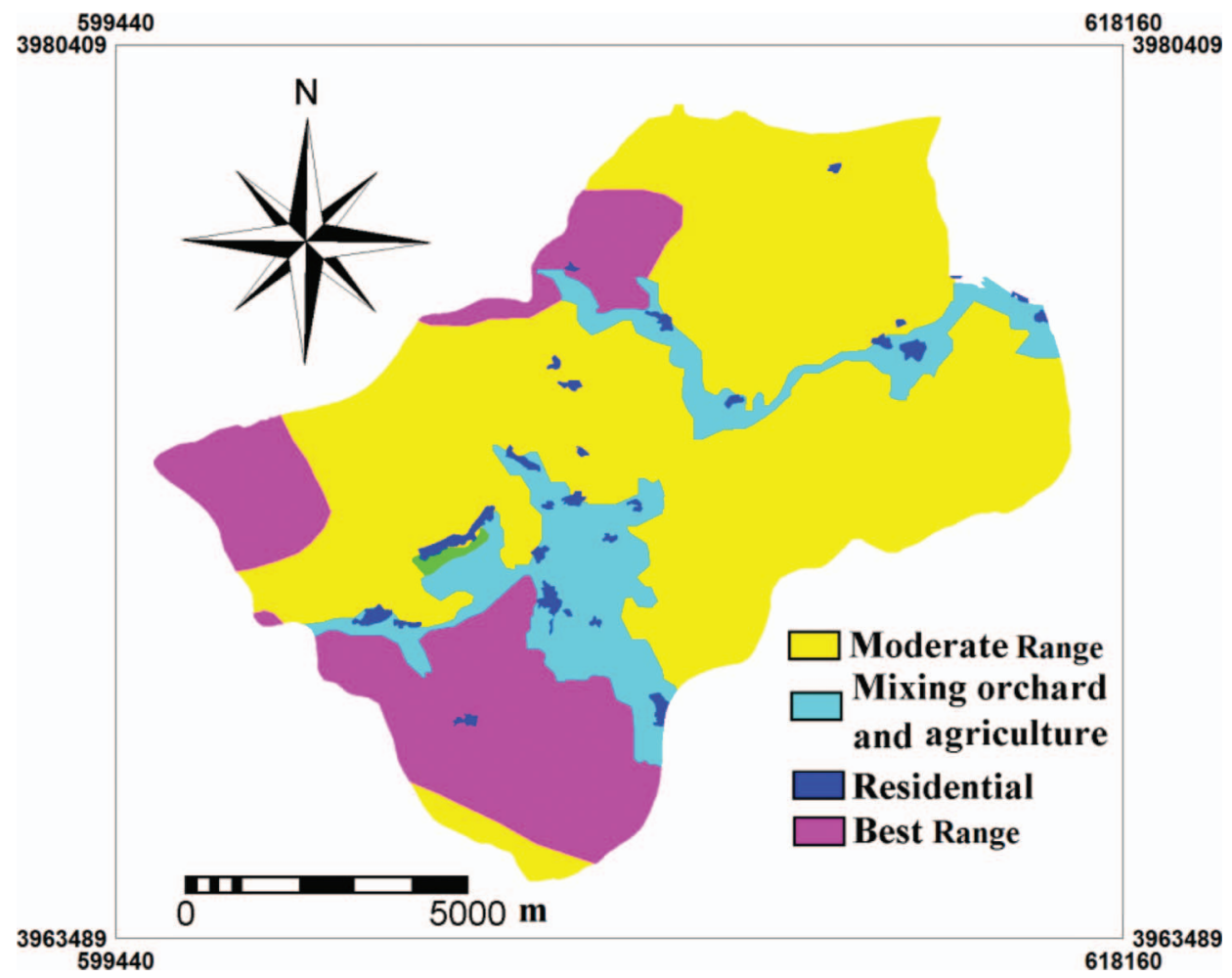

Figure 6. The land use map of the study area.

weights-of-evidence model can be calculated by employing the natural logarithm of the likelihood ratio in equation 6 that ranges from 0 to infinity. This means that, derivation of mass functions from two likelihood ratio functions is required. The likelihood ratios are separated by the sum of likelihood ratio values of whole class attributes in the given evidence $B_{i}$, not only to satisfy the standardization condition in equation 6 but also to account for the relative importance inside class attribute amounts (Park 2011):

$$
\begin{aligned}
& m: 2^{\Theta} \rightarrow[0,1]\left\{\begin{array}{c}
m(\phi)=0 \\
\sum_{T \subset \Theta} m(T)^{1}
\end{array}\right. \\
& \left(T_{P}\right) B_{i j}=\frac{\lambda\left(T_{P}\right)_{B_{i j}}}{\sum \lambda\left(T_{P}\right)_{B_{i j}}} \\
& m\left(\overline{T_{P}}\right)_{B_{i j}}=\frac{\lambda\left(\overline{T_{P}}\right)_{B_{i j}}}{\sum \lambda\left(\overline{T_{P}}\right)_{B_{i j}}} \\
& m(\Theta)=1-m\left(T_{P}\right)_{B_{i j}}-m\left(\overline{T_{P}}\right)_{B_{i j}}
\end{aligned}
$$

Considering the equation 7 , the belief function can be directly derived from the mass function $m\left(T_{P}\right)_{B_{i j}}$, for supporting the positive target proposition, and the plausibility 
function can also be computed by $1-m\left(\overline{T_{P}}\right)_{B_{i j}}$. When defining the belief and plausibility functions from likelihood ratio functions, two specific constraints depended to landslide occurrences are attended independently. When no landslides have created in the given attribute $B_{i j}$, this corresponds that there is no belief for the target proposition (i.e. $m\left(T_{P}\right)_{B_{i j}}=0$ ). In any case, this does not mean that the disbelief should be committed to its complement $m\left(\overline{T_{P}}\right)_{B_{i j}}$, and this study considers the existing of uncertainty. Thus, $m\left(\overline{T_{P}}\right)_{B_{i j}}$ is obliged to 0 and as a result, $m(\Theta)_{B_{i j}}$ is set to 1 . The complementary second constraint is related to landslide occurrences. In some cases, the first constraint cannot be directly applied. For example, landslides cannot occur in flat areas (zero slope values), thus no belief is committed to $m\left(T_{P}\right) B_{i j}$. The disbelief should be 0 and $m(\Theta)_{B_{i j}}$ should be 1 , when applying the first constraint, while the disbelief is forced to 1 , considering the second. So, in the flat areas, $m\left(T_{P}\right) B_{i j}$ and $m(\Theta)_{B i j}$ are set to 0 , and $m(\Theta)_{B_{i j}}$ (Park 2011).

Based on, equations 6 and 7 three mass functions, $m\left(T_{P}\right), m\left(\bar{T}_{p}\right)$, and $m(\Theta)$ were calculated which correspond to belief, disbelief, and ignorance functions, respectively (table 2). For example in the slope aspect map, most landslides occurred in the west facing and so the highest mass function amount was obtained. The higher amounts of the belief function in that class leads to the lower amounts of the disbelief and ignorance functions. Also, based on total weight amount, the susceptibility map for Haraz Watershed was prepared using DST (figure 7).

\subsection{Landslide susceptibility mapping by Weights-of-evidence model}

In this theory, for each of the factors, the weights and contrast were calculated using the weights-of-evidence model. The magnitude of the contrast, $C$, was determined from the difference, $W^{+}$and $W^{-}$; it provided a measure of the spatial association between a set of points and a binary pattern (Bonham-Carter et al. 1989). C is positive for a positive spatial association and negative for a negative spatial association. The Studentised value of $C$, the ratio of $C$ to its standard deviation or $C / S(C)$, serves as a guide to the significance of the spatial association and acts as a measure of the relative certainty of the posterior probability (Bonham-Carter 1994). The weights and contrasts for each predictor pattern are summarized in table 2. The contrast was set to the rating of each landslide conditioning factor, as the contrast is related to the landslide probability. There were 1,144,281 total pixels in the study area. The ratio $W^{+}$is the percentage of landslides/percentage of the domain and C is the contrast. $S^{2}\left(W^{+}\right)$and $S^{2}\left(W^{-}\right)$are the variances of $W^{+}$and $W^{-}$. $S(C)$ is the standard deviation of the contrast, and $C / S(C)$ is the Studentised value of the contrast (table 3 ). The Studentised value of $C$, serves as a guide to the significance of the spatial association and acts as a measure of the relative certainty of the posterior probability (Bonham-Carter 1994). The standard deviation of $C$ is calculated by

$$
S(C)=\sqrt{S^{2}\left(W^{+}\right)+S^{2}\left(W^{-}\right)}
$$

The relationships between the landslides and the landslide-related factors, contrast and Studentised $C$ are presented in table 2. The pixel values obtained are then classified into four classes (low, moderate, high and very high) based on natural 

舟|

鹿

离

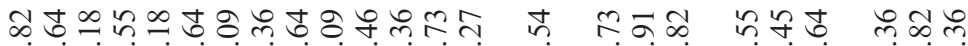

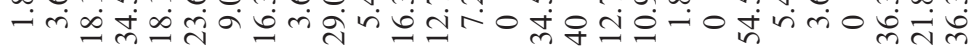

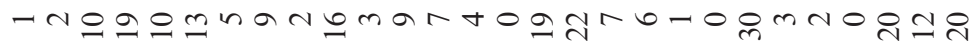

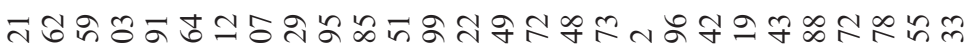
-

చ

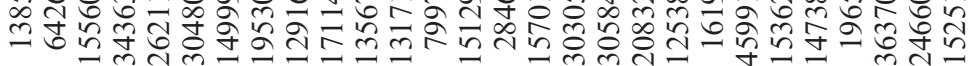
$\dot{0} . \Xi$ (1)

0
0
0
0

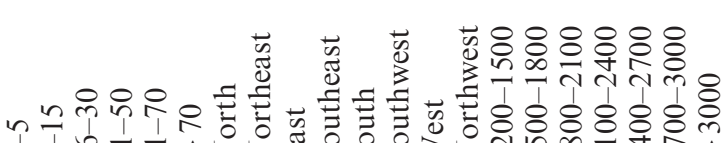

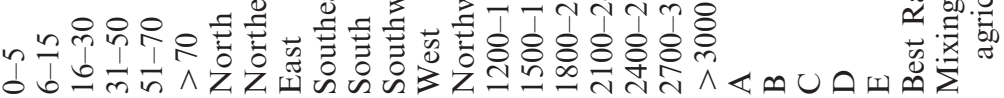

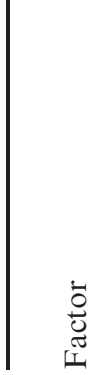
0
0
0
0
0
0
0
00
0
0
0
$\frac{0}{2}$

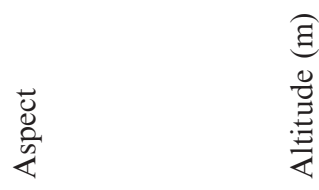

छ્g
$\frac{0}{\Xi}$
$\stackrel{\Xi}{\Xi}$ 


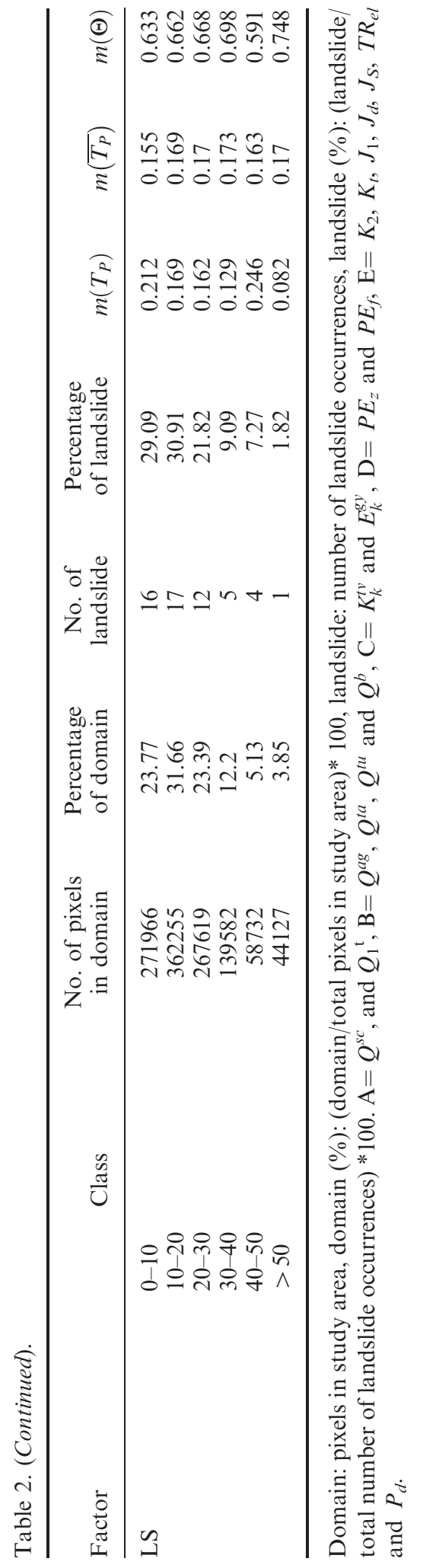




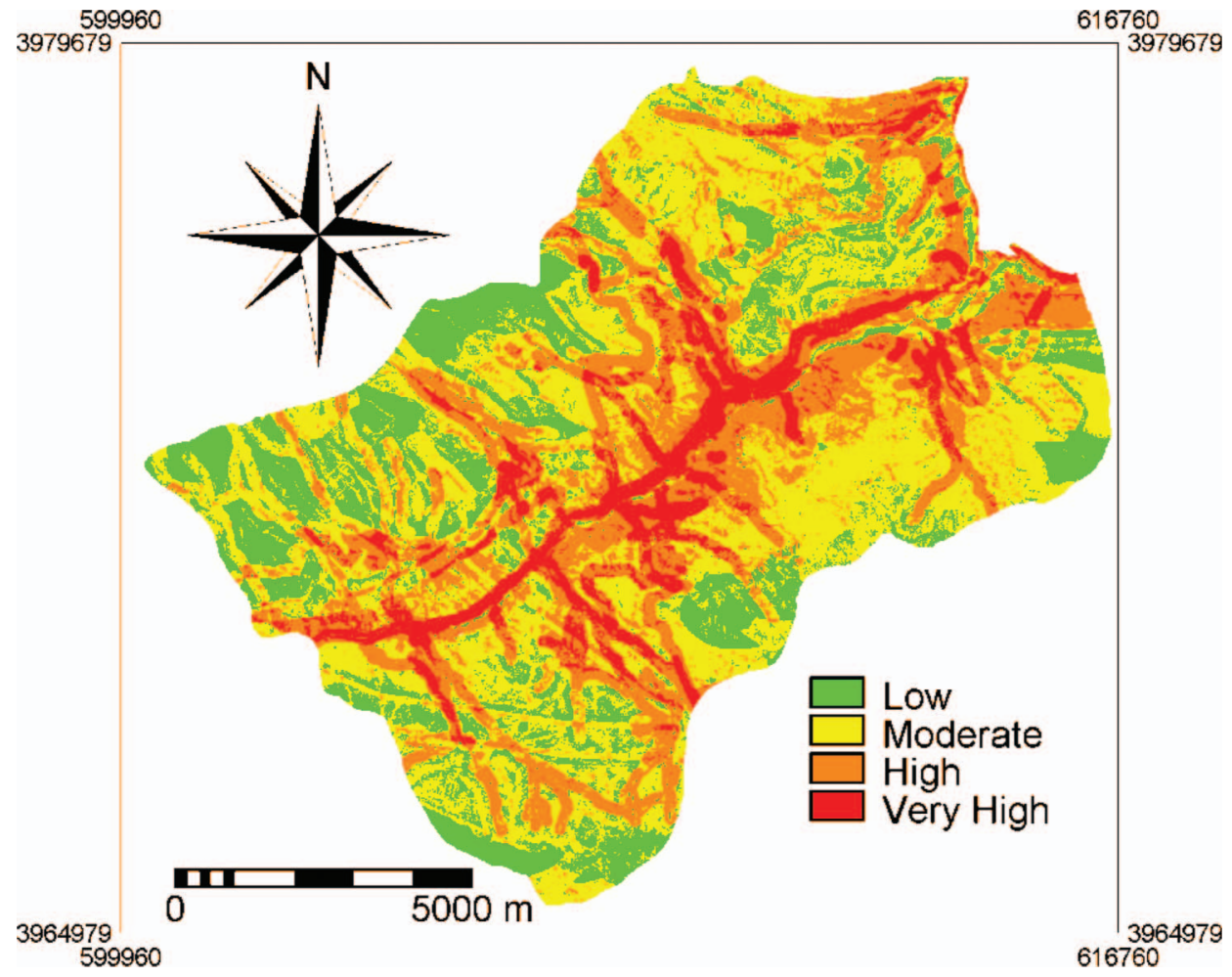

Figure 7. Landslide susceptibility map produced by Dempster-Shafer theory.

classification scheme to determine the class intervals in the landslide susceptibility map (figure 8).

To establish the spatial relationship between the landslide and landslide conditioning factors, a frequency ratio analysis was performed. Frequency ratio approaches are based on the observed relationships between distribution of landslides and each landslide-related factor, to reveal the correlation between landslide locations and the factors in the study area (Pradhan and Lee 2010a). In the frequency ratio relationships analysis, the ratio is that of the area where landslides occurred to the total area, so that a value of 1 is an average value. If the value is $>1$, it means a higher correlation, and a value lower than 1 means a lower correlation. For slope angles $6-15$, the frequency ratio was 0.65 , which indicates a very low probability of landslide occurrence (table 3). For slopes between 16 and 50, the ratio was $>1$, which indicates a high probability of landslide occurrence (table 3 ). However, for the slope $<5$, the frequency ratio value was 1.51 . This is because only one landslide has occurred in a relatively low number of pixel domain.

In the case of the slope aspect (table 3), landslides were most abundant on southeast and west-facing slopes. The frequency of landslides was lowest on eastfacing, south-facing and north-facing slopes. In the case of altitude (table 3 ), the frequency ratios $>1$ at intervals $1500-1800 \mathrm{~m}$ and $1800-2100 \mathrm{~m}$ (2.52 and 1.51 respectively). Results showed that the ratio decrease with the increase of altitude. In the case of lithology (table 3), the frequency ratio was higher (1.36) in quaternary 


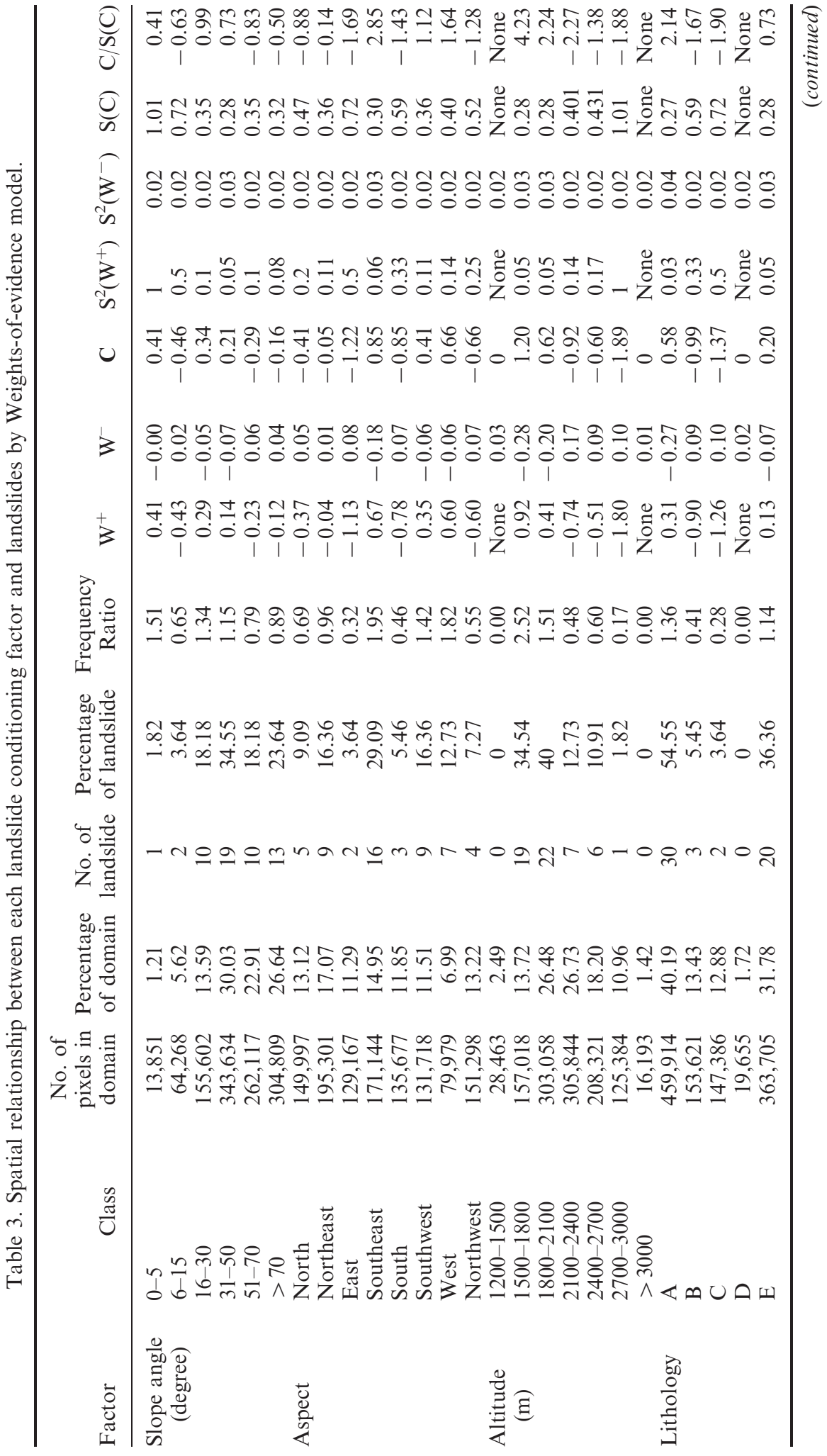




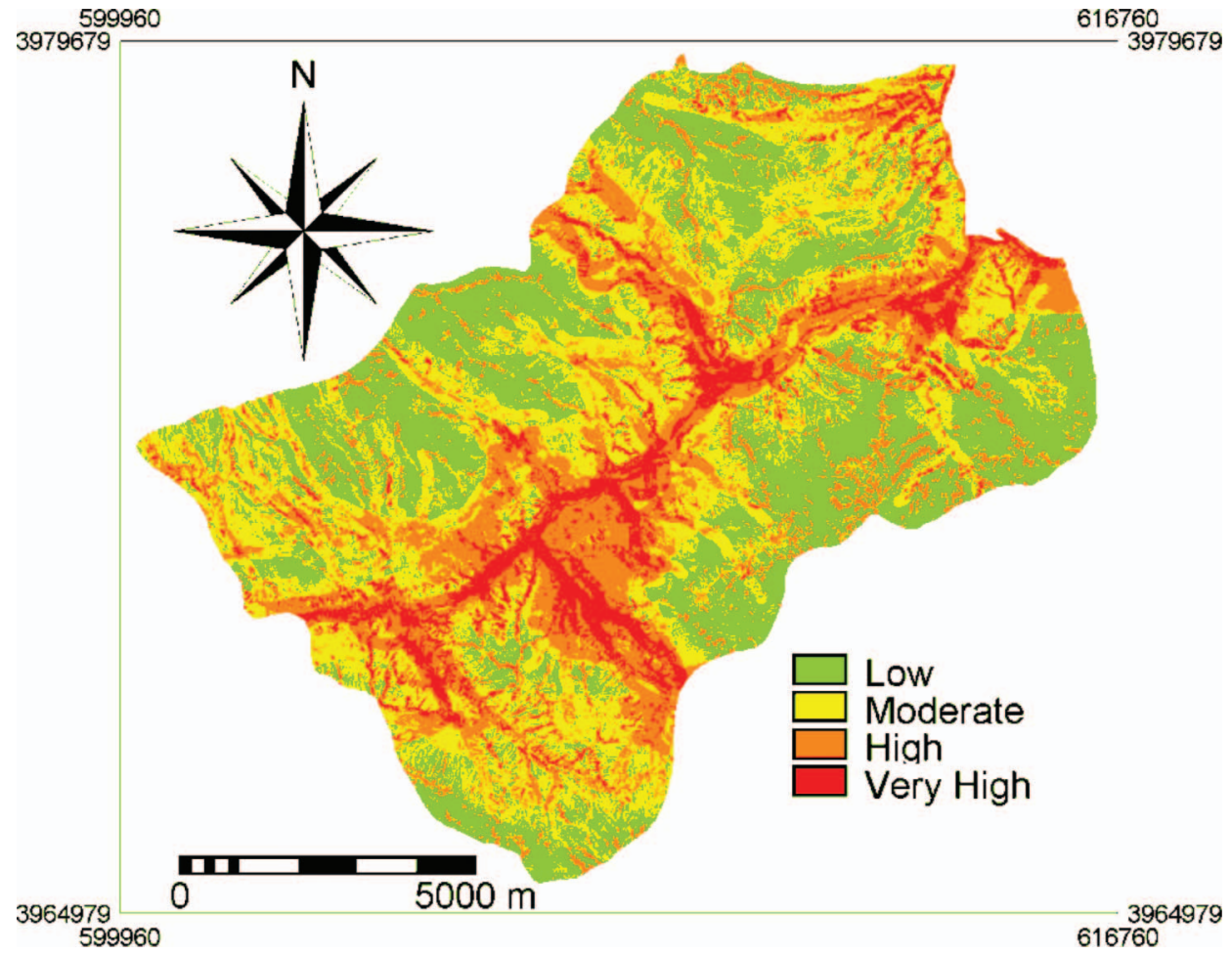

Figure 8. Landslide susceptibility map produced by Weights-of-evidence model.

deposits (class A), and lower (0.00) in Paleocene age (class D). In the case of land use (table 3), the landslide-occurrence values were higher in residential areas (6.07), and lower in middle pasture areas (0.62).

In the case of distance from fault (table 3), for distances $300-400 \mathrm{~m}$, and $>400 \mathrm{~m}$ the ratio is 0.93 , and 0.86 , respectively, indicating a low probability of landslide occurrence. Subsequently, at distances of 0-100 m, 100-200 and 200-300 m, the frequency ratios are $1.39,1.93$ and 2.89 , respectively, indicating a high probability. This means that the landslide probability decreases with increasing distance from fault lines. For the distance from river (table 3), it can be seen that the frequency ratio $>1$ at distance from river of $0-100 \mathrm{~m}$, whereas the values of frequency ratios $<1$ are at distances from river of 100-200 m, 200-300 m, 300-400 m and $>400 \mathrm{~m}$. From this observation, we can say that the general trend of the ratio decreases with the distance from the river. This can be attributed to the fact that terrain modification is caused by gully erosion, which may influence the initiation of landslides. For the distance from road, frequency ratio are 3.51 and 1.11 at distance of $0-100 \mathrm{~m}$, and $200-300 \mathrm{~m}$ respectively, whereas the values of frequency ratios $<1$ at distances of 100-200 m, 300-400 m, 400-500 m and > 500 m. From this observation, we can say that the general trend of the ratio decreases with the distance from the road. In the case of CTI, frequency ratio is higher for the class 0-4 and $8-12$. In the case of SPI, and LS, frequency ratios are higher (i.e. $>1$ ) for the range 0-20 and 40-50 respectively. 

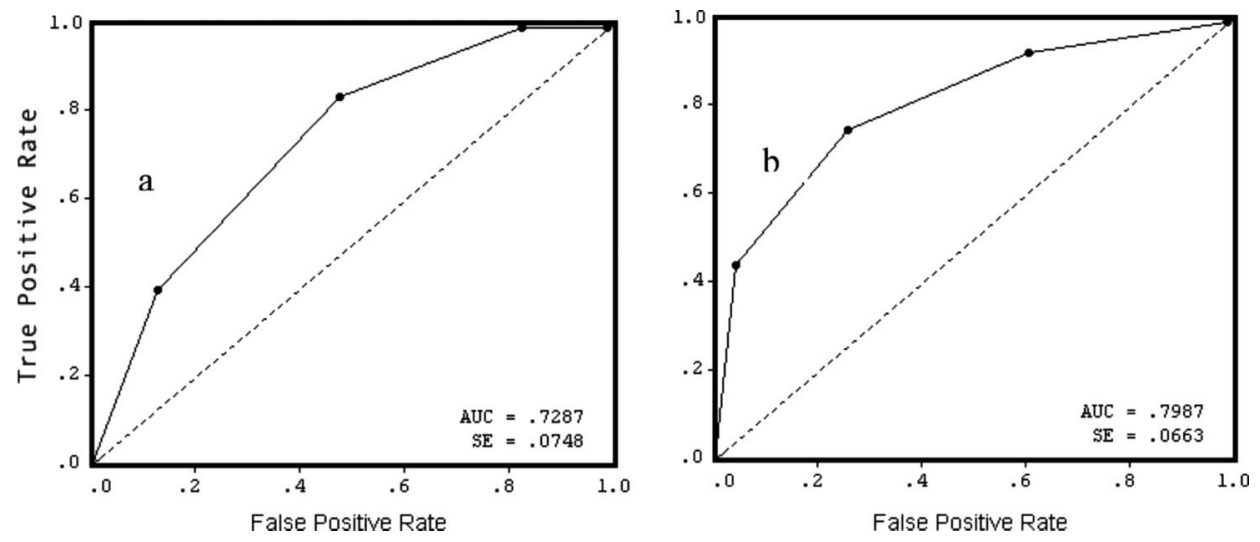

Figure 9. ROC curve for the susceptibility maps produced by (a) Dempster-Shafer theory and (b) Weights-of-Evidence model.

\subsection{Validation and comparison of the landslide susceptibility maps}

The critical strategy in prediction models is the task of validating the predicted results, so that the prediction results can provide meaningful interpretation with respect to the future landslides. To apply the validation, we must restrict using all of past landslides data in the study area. By partitioning the data, one subset is used for obtaining a prediction map; the other subset is compared with the prediction results. For the purpose of validation, the learning set of landslides was randomly selected from a total of 78 landslides location ( 55 or $70 \%$ of landslides with similar portions for each landslide type) disregarding the temporal component. Here, the model development set is almost twice as big as the testing set. Then, the validation was performed using the receiver operating characteristic (ROC) curve (Pradhan and Lee 2010a, 2010b). In the ROC curve, the sensitivity of the model (in our case, the percentage of unstable pixels correctly predicted by the model) is plotted against 1 -specificity (the percentage of predicted unstable pixels over the total). These values indicate the ability of the model to correctly discriminate between positive and negative observations in the validation sample. High sensitivity indicates a high number of correct predictions (true positives) whereas high specificity (low 1 -specificity difference) indicates a low number of false positives. For instance, a conservative model, which predicts most of the cells as unstable, would have high sensitivity but low specificity (high number of false positives). The area under the ROC curve (AUC) can serve as global accuracy statistic for the model and it is threshold-independent. This statistical ranges from 0.5 (random prediction, represented by the diagonal straight line) to 1 (perfect prediction) and can be used for models comparison (Cervi et al. 2010). The results showed a $72.87 \%$ and $79.87 \%$ for Dempster-Shafer and Weights-of-evidence models, respectively (figure 9).

\section{Conclusions}

Landslides in mountainous areas cause enormous loss of life and property every year. Due to their hazardous character, many government and research institutions throughout the world have attempted to assess landslide susceptibility, hazards, and 
risks and to show their spatial pattern over the years. In such areas, landslide susceptibility mapping is essential to delineate the landslide prone area. Various methodologies have been proposed for landslide susceptibility mappings. In this study, two GIS-based methodologies for landslide susceptibility mapping were tested in a landslide prone area, north Iran, and the outputs were compared.

In the first stage of the study, an extensive landslide inventory mapping study was performed because a reliable landslide inventory map is necessary for all indirect landslide susceptibility evaluations. For this purpose, a landslide inventory database that is used to assess the landslide susceptibility of the study area, with a total of 78 landslides, was mapped in the study area. In the second stage, the landslide conditioning factors were determined, and these were prepared for the landslide susceptibility assessment by Dempster-Shafer and Weights-of-evidence models. Finally, for the purpose of validation, the learning set of landslides was randomly selected from a total of 78 landslides population (55 or $70 \%$ of landslides with similar portions for each landslide type) disregarding the temporal component. The ROC curve produced based on the test data set, which was randomly collected from landslide bodies and safe zones. The results showed a $72.87 \%$ and $79.87 \%$ with a standard error of 0.0748 and 0.0663 for Dempster-Shafer and Weights-ofevidence models, respectively. So, the performance of the produced map by Weights-of-evidence model is obviously higher than that of the map produced by Dempster-Shafer theory. Prepared landslide prediction map could be the basis for decisions making. The information provided by this landslide susceptibility map could help citizens, planners and engineers to reduce losses caused by existing and future landslides by means of suitable preventive measures and mitigation procedures. If the factors related to the tectonic activity, vulnerability of buildings and other property were available, a hazard and risk analysis could also be performed.

\section{Acknowledgements}

Authors would like to thank two anonymous reviewers and Ramesh P. Singh for their critical and valuable review which helped us to bring the manuscript to the current form.

\section{References}

Akgun, A. and Turk, N., 2010, Landslide susceptibility mapping for Ayvalik (Western Turkey) and its vicinity by multicriteria decision analysis. Environmental Earth Sciences, 61, pp. 595-611.

Beven, K. and Kirkby, M.J., 1979, A physically based, variable contributing area model of basin hydrology. Hydrological Sciences Bulletin, 24, pp. 43-69.

Bonham-Carter, G.F. 1994 Geographic Information Systems for Geoscientists: Modeling with GIS (Oxford: Pergamon).

Bonham-Carter, G.F., Agterberg, F.P. and Wright, D.F., 1989, Weights-of-evidence modeling: a new approach to mapping mineral potential. In Statistical Applications in the Earth Sciences, F.P. Agterberg and G.F. Bonham-Carter (Eds), paper 89-9, pp. 171-183 (Ottawa: Geological Survey Canada).

Bui, D.T., Lofman, O., Revhaug, I. and Dick, O., 2011a, Landslide susceptibility analysis in the Hoa Binh province of Vietnam using statistical index and logistic regression. Natural Hazards, 59, pp. 1413-1444. 
Bui, D.T., Pradhan, B., Lofman, O., Revhaug, I. and Dick, O.B, 2011b, Landslide susceptibility mapping at Hoa Binh province (Vietnam) using an adaptive neuro-fuzzy inference system and GIS. Computers \& Geosciences, (Article in press) DOI: 10.1016/ j.cageo.2011.10.031

Can, T., Nefeslioglu, H.A., Gokceoglu, C., Snomez, H. and Duman, T.Y., 2005, Susceptibility assessment of shallow earth flows triggered by heavy rainfall at three sub catchments by logistic regression analyses. Geomorphology, 72, pp. 250-271.

Carrara, A., Cardinali, M., Guzzetti, F. and Reichenbach, P., 1995, GiS-based Techniques for Mapping Landslide Hazard, Chapter "GIS technology in mapping landslide hazard", Geographical Information Systems in Assessing Natural Hazards, p. 38 (Dordrecht, the Netherlands: Kluwer).

Cervi, F., Berti, M., Borgatti, L., Ronchetti, F., Manenti, F. and Corsini, A., 2010, Comparing predictive capability of statistical and deterministic methods for landslide susceptibility mapping: a case study in the northern Apennines (Reggio Emilia Province, Italy). Landslides, 7, pp. 433-444.

Champati Ray, D.P., Dimri, S., Lakhera, R.C. and Sati, S., 2007, Fuzzy-based method for landslide hazard assessment in active seismic zone of Himalaya. Landslides, $\mathbf{4}$, pp. 101-111.

Chauhan, S., Sharma, M., Arora, M.K. and Gupta, N.K., 2010, Landslide susceptibility zonation through ratings derived from artificial neural network. International Journal of Applied Earth Observation and Geoinformation, 12, pp. 340-350.

Cruden, D.M., 1991, A simple definition of a landslide. Bulletin of the International Association of Engineering Geology, 43, pp. 27-29.

Dempster, A.P., 1967, Upper and lower probabilities induced by a multi valued mapping. The Annals of Mathematical Statistics, 28, pp. 325-339.

Ercanoglu, M. and Gokceoglu, C., 2002, Assessment of landslide susceptibility for a landslide-prone area (north of Yenice, NW Turkey) by fuzzy approach. Environmental Geology, 41, pp. 720-730.

Ercanoglu, M. and Gokceoglu, C., 2004, Use of fuzzy relations to produce landslide susceptibility map of a landslide prone area (West Black Sea Region, Turkey). Engineering Geology, 75, pp. 229-250.

Ermini, L., Catani, F. and Casagli, N., 2005, Artificial neural networks applied to landslide susceptibility assessment. Geomorphology, 66, pp. 327-343.

Gerath, R., Hunger, O. and VAN DINE, D., 1997, Terrain Stability Mapping in British Columbia, (Province of British Columbia: Resources inventory committee). Available online at: http:// srmwww.gov.bc.ca/risc/ pubs/earthsci/terrain2 (accessed 4 August 2011).

Gokceoglu, C., Snomez, H., Nefeslioglu, H.A., Duman, T.Y. and Can, T., 2005, The March 17, 2005 Kuzulu landslide (Sivas, Turkey) and landslide susceptibility map of its near vicinity. Engineering Geology, 81, pp. 65-83.

Gorsevski, P.V. and JANKOwSKI, P., 2010, An optimized solution of multi-criteria evaluation analysis of landslide susceptibility using fuzzy sets and Kalman filter. Computers \& Geosciences, 36, pp. 1005-1020.

Gorsevski, P.V., Gessler, P.E., Foltz, R.B. and Elliot, W.J., 2006, Spatial prediction of landslide hazard using logistic regression and ROC analysis. Transactions in GIS, 10, pp. 395-415.

Guzzetti, F., Carrara, A., Cardinalli, M. and Reichenbach, P., 1999, Landslide hazard evaluation: A review of current techniques and their application in a multi-case study, central Italy. Geomorphology, 31, pp. 181-216.

Iranian Landslide Working Party (ILWP), 2007, Iranian landslides list, p. 60 (Tehran, Iran: Forest, Rangeland and Watershed Association).

Kanungo, D.P., Arora, M.K., Gupta, R.P. and Sarkar, S., 2008, Landslide risk assessment using concepts of danger pixels and fuzzy set theory in Darjeeling Himalayas. Landslides, 5, pp. 407-416. 
LeE, S. and ChOI, J., 2004, Landslide susceptibility mapping using GIS and the weight-ofevidence model. International Journal of Geographical Information Science, 18, pp. 789-814.

Lee, S., Сно, J. and Он, Н., 2009, Landslide susceptibility mapping using a neuro-fuzzy, Abstract presented at American Geophysical Union, Fall Meeting 2009, abstract \#NH53A-1075.

Lee, S., Rye, J.H., LeE, M.J. and Won, J.S., 2006, The application of artificial neural networks to landslide susceptibility mapping at Janghung, Korea. Mathematical Geololgy, 38, pp. 199-219.

Mathew, J., Jha, V.K. and Rawat, G.S., 2007, Weights of evidence modelling for landslide hazard zonation mapping in part of Bhagirathi valley, Uttarakhand. Current Science, 92, pp. 628-638.

Moore, I.D. and Burch, G.J., 1986, Sediment transport capacity of sheet and rill flow: application of unit stream power theory. Water Researches Research, 22, pp. 1350-1360.

Moore, I.D., Grayson, R.B. and Ladson, A.R., 1991, Digital terrain modeling: a review of hydrological, geomorphological, and biological applications. Hydrological Processes, 5, pp. 3-30.

Moore, I.D. and WiLSON, J.P., 1992, Length-slope factors for the revised universal soil loss equation: simplified method of estimation. Journal of Soil and Water Conservation, 47, pp. $423-428$.

Nefeslioglu, H.A., Duman, T.Y. and Durmaz, S., 2008, Landslide susceptibility mapping for a part of tectonic Kelkit Valley (Eastern Black Sea region of Turkey). Geomorphology, 94, pp. 401-418.

Nefeslioglu, H.A., Sezer, E., Gokceoglu, C., Bozkir, A.S. and Duman, T.Y., 2010, Assessment of landslide susceptibility by decision trees in the Metropolitan area of Istanbul, Turkey. Mathematical Problems in Engineering, 2010, Article ID 901095, pp. 1-15. doi: 10.1155/2010/901095

Neuhauser, B. and Terhorst, B., 2007, Landslide susceptibility assessment using "weights-ofevidence" applied to a study area at the Jurassic escarpment (SW-Germany). Geomorphology, 86, pp. 12-24.

Nilsen, T.H., Wright, R.H., Vlasic, T.C. and Spangle, W.E., 1979, Relative slope stability and land-use planning in the San Francisco Bay region, p. 944 (Aquifer, CA: US Geological Survey Professional).

Оh, H.-J. and Pradhan, B., 2011, Application of a neuro-fuzzy model to landslidesusceptibility mapping for shallow landslides in a tropical hilly area. Computers \& Geosciences, 37, pp. 1264-1276.

PARK, N.W., 2011, Application of Dempster-Shafer theory of evidence to GIS-based landslide susceptibility analysis. Environmental Earth Sciences, 62, pp. 367-376.

Poudyal, C.P., Chang, C., OH, H.J. and Lee, S., 2010, Landslide susceptibility maps comparing frequency ratio and artificial neural networks: a case study from the Nepal Himalaya. Environmental Earth Sciences, 61, pp. 1049-1064.

Pourghasemi, H.R., 2008, Landslide hazard assessment using fuzzy logic (case study: a part of Haraz Watershed), a thesis presented for M.Sc. degree in watershed management. Faculty of Natural Resources, Department of Watershed Management, Tarbiat Modarres University, Iran, p. 92.

Pradhan, B., 2010a, Remote sensing and GIS-based landslide hazard analysis and cross validation using multivariate logistic regression model on three test areas in Malaysia. Advances in Space Research, 45, pp. 1244-1256.

Pradhan, B., 2010b, Application of an advanced fuzzy logic model for landslide susceptibility analysis. International Journal of Computational Intelligence Systems, 3, pp. 370-381.

Pradhan, B., 2010c, Landslide susceptibility mapping of a catchment area using frequency ratio, fuzzy logic and multivariate logistic regression approaches. Journal of the Indian Society of Remote Sensing, 38, pp. 301-320. 
Pradhan, B., 2011a, Manifestation of an advanced fuzzy logic model coupled with geoinformation techniques for landslide susceptibility analysis. Environmental and Ecological Statistics, 18, pp. 471-493.

Pradhan, B., 2011b, Use of GIS based fuzzy relations and its cross application to produce landslide susceptibility maps in three test areas in Malaysia. Environmental Earth Sciences, 63, pp. 329-349.

Pradhan, B. and Buchroithner, M.F., 2010, Comparison and validation of landslide susceptibility maps using an artificial neural network model for three test areas in Malaysia. Environmental \& Engineering Geoscience, 16, pp. 107-126.

Pradhan, B. and LeE, S., 2010a, Regional landslide susceptibility analysis using back-propagation neural network model at Cameron Highland, Malaysia. Landslides, 7, pp. 13-30.

Pradhan, B. and Lee, S., 2010b, Delineation of landslide hazard areas on Penang Island, Malaysia, by using frequency ratio, logistic regression, and artificial neural network models. Environmental Earth Sciences, 60, pp. 1037-1054.

Pradhan, B. and Lee, S., 2010c, Landslide susceptibility assessment and factor effect analysis: back-propagation artificial neural networks and their comparison with frequency ratio and bivariate logistic regression modelling. Environmental Modelling \& Software, 25, pp. 747-759.

Pradhan, B., Lee, S. and Buchroithner, M.F., 2010a, Remote sensing and GiS-based landslide susceptibility analysis and its cross-validation in three test areas using a frequency ratio model. Photogrammetrie, Fernerkundung, GeoInformation, 1, pp. $17-32$.

Pradhan, B., OH, H.J. and Buchroithner, M.F., 2010b, Weights-of-evidence model applied to landslide susceptibility mapping in a tropical hilly area. Geomatics, Natural Hazards and Risk, 1, pp. 199-223.

Pradhan, B., Sezer, A.E., Gokceoglu, C. and Buchroithner, M.F., 2010c, Landslide susceptibility mapping by neuro-fuzzy approach in a landslide prone area (Cameron Highland, Malaysia). IEEE Transactions on Geoscience and Remote Sensing, 48, pp. $4164-4177$.

Pradhan, B. and Pirasteh, S., 2010, Comparison between prediction capabilities of neural network and fuzzy logic techniques for landslide susceptibility mapping. Disaster Advances, 3, pp. 26-34.

Pradhan, B. and Youssef, A.M., 2010, Manifestation of remote sensing data and GIS for landslide hazard analysis using spatial-based statistical models. Arabian Journal of Geosciences, 3, pp. 319-326.

Saito, H., Nakayama, D. and Matsuyama, H., 2009, Comparison of landslide susceptibility based on a decision-tree model and actual landslide occurrence: The Akaishi Mountains, Japan. Geomorphology, 109, pp. 108-121.

Sezer, E.A., Pradhan, B. and Gokceoglu, C., 2011, Manifestation of an adaptive neurofuzzy model on landslide susceptibility mapping: Klang Valley, Malaysia. Expert Systems with Applications, 38, pp. 8208-8219.

Shafer, G., 1976, A mathematical theory of evidence (Princeton, NJ: Princeton University Press).

Soeters, R. and van Westen, C.J., 1996, Slope stability: recognition, analysis and zonation. In "Landslides: investigation and mitigation". Transportation Research Board-National Research Council. Special Report 247, A.K., Turner and R.L., SHuster (Eds), pp. 129177 (Washington, DC: National Academy Press).

Tangestani, M.H., 2009, A comparative study of Dempster-Shafer and fuzzy models for landslide susceptibility mapping using a GIS: An experience from Zagros Mountains, SW Iran. Journal of Asian Earth Sciences, 35, pp. 66-73.

Vahidnia, M.H., Alesheikn, A.A., Alimohammadi, A. and Hosseinali, F., 2010, A GiS-based neurofuzzy procedure for integrating knowledge and data in landslide susceptibility mapping. Computers \& Geosciences, 36, pp. 1101-1114. 
van Westen, C.J., Rengers, N. and Soeters, R., 2003, Use of geomorphological information in indirect landslide susceptibility assessment. Natural Hazards, 30, pp. 399-419.

VARnes, D.J., 1978, Slope movement types and processes. In: Landslides Analysis and Control. Special Report, vol 176, R.L. Schuster and R.J. KrizeK (Eds), pp. 12-33 (New York: Transportation Research Board, National Academy of Sciences).

VARnes, D.J., 1984, With IAEG Commission on Landslides and Other Mass Movements: Landslide Hazard Zonations: A Review of Principles and Practices, p. 63 (Paris: UNESCO).

WAN, S., 2009, A spatial decision support system for extracting the core factors and thresholds for landslide susceptibility map. Engineering Geology, 108, pp. 237-251.

Yalcin, A., Reis, S., Aydinoglu, A.C. and Yomalioglu, T., 2011, A GiS-based comparative study of frequency ratio, analytical hierarchy process, bivariate statistics and logistics regression methods for landslide susceptibility mapping in Trabzon, NE Turkey. Catena, 85, pp. 274-287.

Yeon, Y.K., Han, J.G. and Ryu, K.H., 2010, Landslide susceptibility mapping in Injae, Korea, using a decision tree. Engineering Geology, 116, pp. 274-283. 